\title{
SPREAD OF ALIEN PLANT SPECIES IN THE HABITATS OF THE UKRAINIAN FOREST STEPPE
}

\author{
NATALIIA PASHKEVYCH, RAISA BURDA
}

Institute for Evolutionary Ecology NAS Ukraine, 37, Lebedeva str., 03143 Kiev, Ukraine; e-mail: pashkevych.nataly@ gmail.com

\begin{abstract}
Pashkevych N., Burda R.: Spread of alien plant species in the habitats of the Ukrainian Forest Steppe. Ekológia (Bratislava), Vol. 36, No. 2, p. 121-129, 2017.

In order to assess the level of anthropogenic transformation of the vegetation cover of the nature protected areas located within the Ukrainian Forest Steppe, we have analysed the distribution of alien species in natural and anthropogenic habitats. All recorded species are represented in habitats shaped by human activity: dominated by phanerophytes, which included deciduous and coniferous woodlands as well as shrublands of Rhamno-Prunetea class. The same number of species was found in grassland habitats and is caused by the huge number of potential ecological niches as a result of the complex structure and also by the proximity of transportation networks and watercourses. Biotopes of chamaephytes and nanophanerophytes, though being represented in all the studied sites, often have a very narrow ecological amplitude and occupy small areas, making it difficult for alien species to spread. About one-third of species were recorded across at least three habitat types; such species may be considered eurytopic in their secondary ranges. Most widespread species were Fallopia convolvulus L., Vicia angustifolia Reichard, Ambrosia artemisiifolia L., Conyza canadensis (L.) Cronqist, Phalacroloma annuum (L.) Dumort. and Setaria viridis (L.) P. Beauv. At the same time, there was not a single species that would have occurred in all habitat types. In sum, agricultural lands and ruderal biotopes were highly invaded; three times less alien plant species occurred in woodlands, shrublands, grasslands and wasteland; and only small number of non-native species were restricted to continental water habitats.
\end{abstract}

Key words: alien species, habitat, protected areas, forest steppe.

\section{Introduction}

Habitat concept of biodiversity conservation is a novel approach to practical implementation of environmental protection principles. This approach provides the best solution for the conservation of environment, including anthropogenically transformed habitats and ecosystems. This concept is recognised by the scientific community as a basis for the creation of specially protected natural areas, and implementation of this concept is ensured by a number of international documents (Council Directive 92/43/EEC of 21 May 1992 on the conservation of natural habitats and of wild fauna and flora, Council Directive 79/409/EEC of 2 April 1979 on the conservation of wild birds). Scientific studies of biodiversity under habitat concept in nature conservation field, including the works of Ukrainian scientists, contribute 
to this global trend (Pysek et al., 2003; Braun et al., 2016; Didukh et al., 2012; Kagalo, Prots, 2012; Didukh et al., 2011).

There are many programmes, including The Convention on Biological Diversity (1992) and Eurogard aimed at solving issues of 'floristic pollution'. The cause of this pollution is the penetration and subsequent expansion of many alien species by various pathways. Plant invasions lead to habitat transformation and changes in species composition and are usually accompanied by the reduction of resistance to external influences (Foxcroft et al., 2017).

One of the main objectives of biodiversity conservation is to determine the direct anthropogenic impacts of invasion of alien species on natural habitats and their transformation. The analysis of habitat structure and evaluation of the disturbance mechanisms will facilitate the forecasting of possible changes and help develop recommendations to prevent negative environmental transformations. The reliable indicators of such biotopic changes are invasive alien species, specifically the number of their natural and anthropogenically transformed localities, populations and individuals, the degree of naturalisation and habitats colonisation.

\section{Material and methods}

According to our data, in the forest-steppe zone of Ukraine, there are more than 550 alien species and this number is increasing continuously (Burda et al., 2015). The most susceptible for plant invasions are protected areas experiencing less economic impact and disturbance but being important centres for endemic and rare species with unique 'genotypes'. The studies of invasive species' colonisation in different protected natural areas will enable to assess the current situation and will allow modelling the future development of this process. These valuable data will help determine which alien species have the greatest potential for naturalisation and subsequent colonisation. Current article presents the study results on the distribution of alien species in natural and anthropogenically transformed habitat types in 13 model floras of natural reserve fund in the forest-steppe physiographic zone of Ukraine.

In our study, we have selected 13 model floras of specially protected natural areas of the highest conservation rank in the forest-steppe zone of Ukraine which represent the overall flora of the forest-steppe zone (Fig. 1). In the Left-bank flatland part of Ukraine, the following are situated: nature reserve (NR) Mykhailivska Tsilyna, national park (NP) Ichnianskyi, NP Pyriatynskyi, NP Slobozhanskyi, NP Dvorichanskyi, NP Homilshanski Lisy. In the central and southern parts of Right-bank Ukraine, the following are situated: NR Kanivskyi, NP Holosiivskyi, NP Khotynskyi, NP Karmeliukove Podillia and park of landscape art of national importance Feofaniia. For a better comparative analysis and assessment of alien species expansion trends from neighbouring floras, we have also included in our research the northern areas of forest steppe: NP Mezynskyi (fragment of forest-steppe landscape from Polesye) and NP Sviati Hory in the south (Donetsk forest-steppe).

The 13 selected model floras have been analysed in terms of distribution of alien species in 6 natural and 1 anthropogenic types of habitats (Fig. 1). Habitat types are listed according to the classification of Didukh et al. (2011): continental water habitats, type $C$; wet habitats of grassy, type D; grassland habitats (grasslands, steppes and wasteland), type E; chamaephytes and nanophanerophytes, type F; habitats dominated by phanerophytes, type G; habitats whose development is caused by geomorphologic and accumulative processes, type $H$; habitats shaped by human activity, type $I$.

For each of the 361 alien species, we have confirmed occurrence in all mentioned habitat types. The distribution studies of invasive species are based on the original materials of field studies conducted during the period 2009-2015: 789 phytosociological relevés were performed by authors. We have also used published data and 73 phytosociological relevés made in NR Mykhailivska Tsilyna (courtesy of Dr. Fitsaylo T.V.) and 57 relevés from the NP Karmeliukove Podillia kindly furnished by Dr. Korotchenko I.A. Anthropophitisation index I is calculated according to the anthropophyte share in the general floristic composition (Abramova, Mirkin, 2000). Coenotic affinity of species is given according to the Braun-Blanquet (1921) classification system. For the assessment of model floras, we have proposed the index of biotopical invasibility $\mathrm{I}_{\text {bin }}$. For model flora, the share of alien species $\left(\mathrm{C}_{\mathrm{e}}\right)$ is calculated as the ratio of alien species amount in each habitat type of the model object to the total number of habitats occurring within the object (including habitats with no anthropophyte records) and multiplied by $100 \%$. 


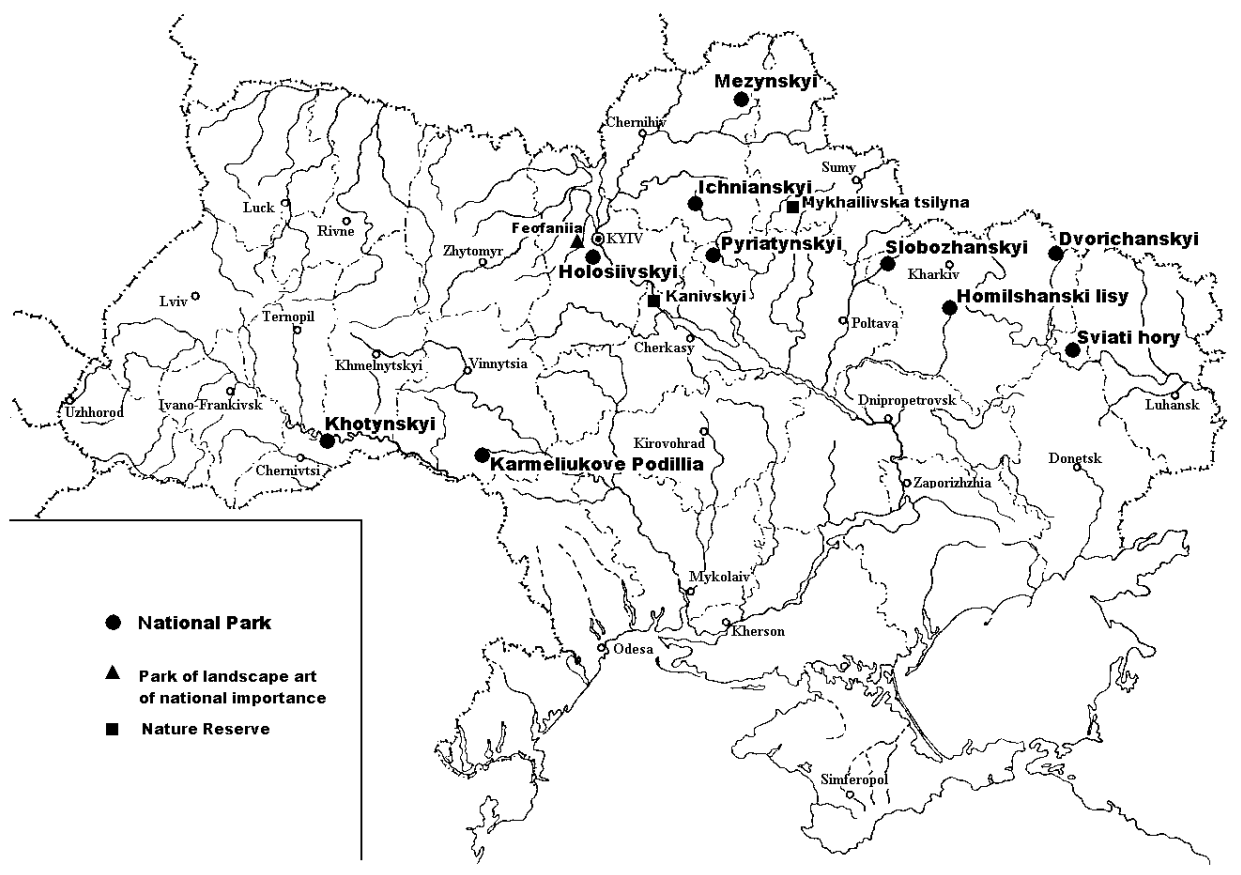

Fig. 1. Distribution of natural resorts fund of the Ukrainian Forest Steppe.

Habitat invasibility index is calculated as the ratio of the alien species share $\left(\mathrm{C}_{\mathrm{e}}\right)$ to the total number of species of model flora. Consequently, using the proposed index of habitat invasibility, susceptibility of habitats and model

$I_{b i n}=\frac{C_{e}}{R}$

$C_{e}=\frac{N_{b 1}+N_{b 2}+\cdots+N_{b n}}{n} \times 100 \%$

where $\mathrm{C}_{\mathrm{e}}$ is the share of alien species in habitats of model flora (protected areas):

$\mathrm{Nb}_{1}$ is the number of alien species in the first habitat,

$\mathrm{Nb}_{2}$ is the number of alien species in the second habitat,

$\mathrm{Nb}_{\mathrm{n}}$ is the number of alien species in the nth biotope,

$\mathrm{n}$ is the number of habitats in the model flora,

$\mathrm{R}$ is the total species number in the model flora.

\section{Results}

Almost all investigated species, 356 (of the total 361) are represented in habitats created by human activities corresponding to type I. Most alien species were observed in the floras labelled NR Kanivskyi, NP Holosiivskyi and NP Pyriatynskyi; accordingly, they belong to type I habitats. In these protected territories, no type $H$ biotopes were identified, whereas 
forest and water habitats are dominant. A significant number of alien species can be explained by the proximity of settlements, for instance, NP Holosiivskyi is located within Kyiv city, Kaniv State Nature Reserve is situated near Kaniv town and the territory NP Pyriatynskyi consists of individual sites segmented by settlements. Another reason for the presence of significant share of anthropophytes could be the location of surveyed territories in the floodplain of the Dnieper or Uday River valley because one of the most important species migration pathways is aquatic. The smallest number of adventive species in anthropogenic habitats has been recorded on NR Mykhailivska Tsilyna and NP Dvorichanskyi - 61 and 66 species, respectively. These protected sites covering small areas have mainly monotypic vegetation. NR Mykhailivska Tsilyna is a unique area of nearly 900 ha, where only five habitat types were identified: swamps (type D), meadow-steppes (type E) and shrub thickets belonging to Rhamno-Prunetea class and Prunion spinosae union (type $G$ and type I). Territories NP Dvorichanskyi with an overall area of about 3,000 ha are located within a massif of steep cretaceous outcrops along the right bank of Oskol River. This object is characterised by well-preserved distinctive cretaceous flora in different habitat types (mainly in $E$ and $H$ ).

Apart from type I habitat, habitats dominated by poaceous and herbaceous species (meadows, steppes and wastelands - type E) are amongst the main recipients of alien species (129 species). The vast majority of colonist species of this habitat type are representatives of richest families of the alien flora of Ukrainian forest steppe: Asteraceae Bercht. \& J.Presl, Poaceae, Fabaceae and Brassicaceae, such as Anisantha tectorum (L.) Nevski, Anthemis arvensis L., A. cotula L., Avena fatua L., Brassica campestris L., Bromus arvensis L., Bunias orientalis L., Carduus acanthoides L., C. nutans L., Cynodon dactylon L., Digitaria sangvinalis (L.) Scop., Hordeum leporinum L., Onopordum acanthium L., Phalacroloma septentrionale (Fernald \& Wiegand) Wagenitz, Sonchus oleraceus L., S. asper (L.) Hill, Setaria viridis and Trifolium hybridum L. The high capacity of this habitat type can be explained by the large number of potential ecological niches. This is determined by the complex habitat structure and proximity of transportation network and watercourses.

Biotopes of type $G$ (forests and shrubs) also undergo significant transformation, overgrown by anthropophytes (125 species), mainly neophytes (Acer negundo L., Amorpha fruticosa L., Impatiens parviflora DC.), including the largest number of phanerophytes capable of occupying appropriate ecological niches. The series of herbaceous plants is represented by mesophytic and xeromesophytic species with different adaptive potential, including a significant proportion of transformer species. Habitats of this type are represented by deciduous and coniferous forests and shrubs of Rhamno-Prunetea class. This vegetation class on one hand serves as a buffer and, on the other hand, is a hot spot for adventive species. Species forming the ecological niche in this biotope are mainly exotic trees and shrubs: Ailanthus altissima (Mill.) Swingle, Celtis occidentalis L., Cotinus coggygria Scop., Juglans cinerea L., J. mandshurica Maxim., J. regia L., Juniperus communis L., Padus serotina Ehrh., P. virginiana L., Ribes nigrum L., R. rubrum L., R. uva-crispa L., which have escaped cultivation. Herbaceous plants such as Anchusa officinalis L., Bryonia alba L., Impatiens parviflora, Lamium purpureum L. and Xanthoxalis stricta L. also occur. Some of them have high invasive potential down to 'transformer species'. 
Habitat type D includes 47 alien species. Amongst them, there are Zizania latifolia (Griseb.) Turcz. ex Stapf and Z. aquatic L. occurring only in the communities of these biotope types of Phragmito-Magnocaricetea vegetation class. The ecological conditions are characterised by the sufficient soil moisture regime, sometimes with the signs of increased soil salinity and acidity. They are also characterised by a low level of competition because of the extreme ecological conditions and are a firm basis for the development of a significant number of adventive mesophytic and hydromesophytic species with an active life strategy and also ephemerophytes associated with the banks of temporary of periodically flooded reservoirs. Amongst them, there are species such as Impatiens glandulifera Royle, Echinochloa crus-gali (L.) P.Beauv., Eragrostis pilosa (L.) P.Beauv., Salix fragilis L., Xanthium strumarium L., X. albinum (Widder) Scholz \& Sukopp and $X$. spinosum L.

Habitats of type $F$ (chamaephytes and nanophanerophytes) are represented by osieries, shrub borders with Frangula alnus and species of Rubus genus, and shrub steppe vegetation. In total, in the habitats of this type, 65 alien species were recorded. This habitat type is characterised by the formation of community structure without clear layer differentiation. Interestingly, amongst the invasive species in the habitats of type $F$, there is a considerable number of vine anthropophyte species: Echinocystis lobata, Cuscuta cesatiana. Perhaps, this phenomenon is a manifestation of 'dense niche packing' principle, where amongst the shrub and subshrub layers, herbaceous plants form a separate horizontal layer and adventive vine species occupy specific vertical niche in competition for light.

Habitats of type $H$ (their development is influenced by geomorphological and accumulative processes) are represented only in four model objects from Left-bank forest steppe of Ukraine (NP Dvorichanskyi, Homilshanski Lisy, Mezynskyi and Sviati Hory). These communities often have very narrow ecological amplitude, and they occupy only small areas in forest-steppe zone, which complicates the penetration of adventive species. Therefore, only alien species with specific edaphic affinity or ubiquist species are registered on this area -49 species in total: Fumaria schleicheri Soy.-Will., F. officinalis L., Veronica persica Poir. ex Lam., Portulaca oleraceae L., Eragrostis minor L., Cardaria draba (L.) Desv., Reseda lutea L., Grindelia squarrosa (Pursh) Dunal.

In habitats of inland water bodies (type $C$ ), alien species of euhydrophytic habitats occur, forming the submerged rooted aquatic vegetation in water column (Elodea canadensis Michx., E. nuttallii (Planch.) H.St.John, Pistia stratiotes L., Vallisneria spiralis L.).

Habitats formed by human activity (type $I$ ) include almost all alien species recorded in our studies (Fig. 2). Amongst the natural habitats, the largest number of species is recorded in grassland habitats (type E) and forests and shrublands (type $G$ ). These habitats incur direct human impact (mowing, grazing and recreation).

About one-third of all species (114) were recorded at least in three types of habitats. These species can be considered eurytopic in their secondary ranges. The most widespread (occurring in all habitats except type C) appeared Fallopia convolvulus (L.) A. Love, Vicia angustifolia, Ambrosia artemisiifolia, Phalacroloma annuum. In five habitats, 25 adventive species occur, amongst them: Chenopodium album L., Conyza canadensis (L.) Cronqist, Lactuca serriola L., Lepidium ruderale L., Oenothera biennis L. We have found 27 species in four habitat types, such as Acer negundo, Amorpha fruticosa, Ballota nigra L., Capsella bursa-pastoris L., Rumex 


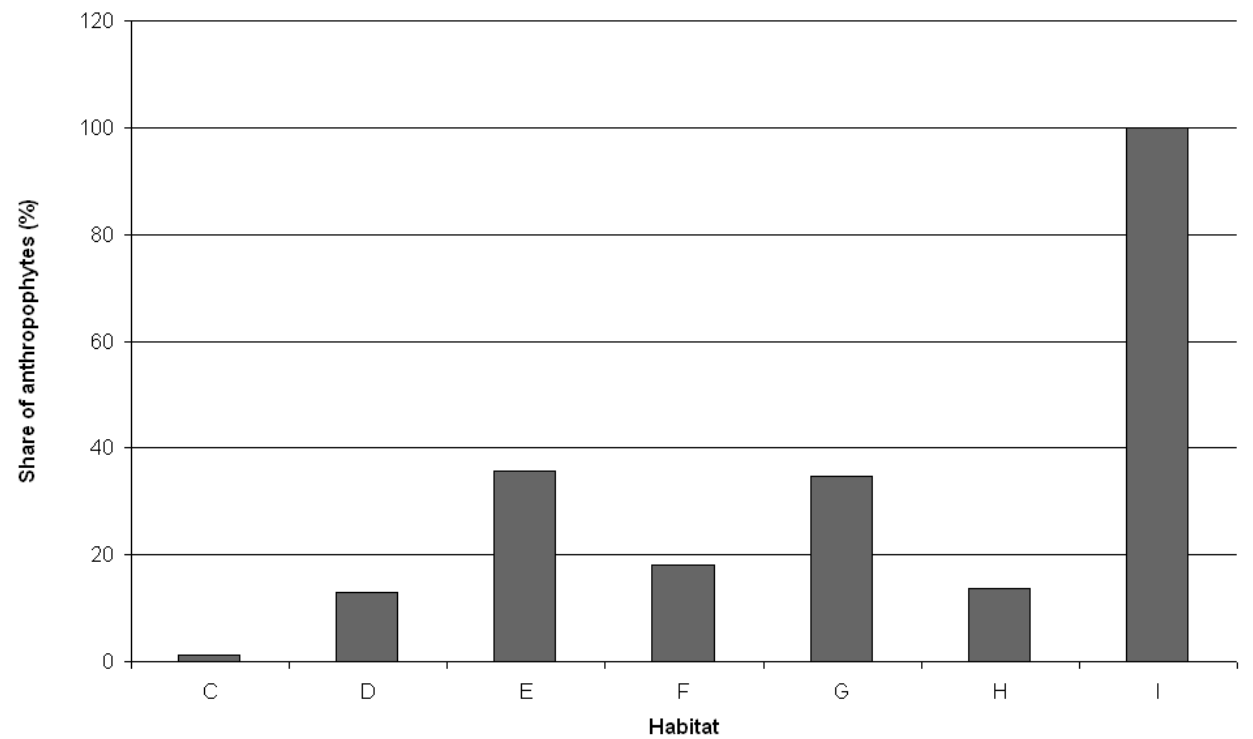

Fig. 2. The distribution of alien species in model floras habitats steppes of Forest Steppe in Ukraine, where type $C$ is the continental water habitats; type $D$ the wet habitats of grassy; type $E$ the grassland habitats (grasslands, steppes and wasteland); type $F$ chamaephytes and nanophanerophytes; type $G$, the habitats dominated by phanerophytes; type $H$ the habitats whose development is caused by geomorphologic and accumulative processes; and type $I$ the habitats shaped by human activity.

T a ble 1. Characteristics of model floras habitats of Forest Steppe in Ukraine for the values of anthropophytisation index.

\begin{tabular}{|l|c|c|c|c|c|c|c|}
\hline \multirow{2}{*}{ Model nature reserve lands } & \multicolumn{7}{|c|}{ Habitat } \\
\cline { 2 - 8 } & C & D & E & F & G & H & I \\
\hline Feofaniia & 0.00 & 3.40 & 17.01 & 3.40 & 29.93 & 0.00 & 97.96 \\
\hline Sviati Hory & 0.70 & 1.41 & 23.94 & 0.00 & 25.35 & 13.38 & 99.30 \\
\hline Homilshanski Lisy & 0.67 & 2.68 & 18.79 & 0.00 & 24.16 & 12.75 & 97.32 \\
\hline Khotynskyi & 0.00 & 26.89 & 26.05 & 21.01 & 25.21 & 0.00 & 94.12 \\
\hline Karmeliukove Podillia & 0.83 & 4.96 & 26.45 & 6.61 & 13.22 & 0.00 & 96.69 \\
\hline Dvorichanskyi & 5.80 & 1.45 & 18.84 & 8.70 & 15.94 & 2.90 & 95.65 \\
\hline Kanivskyi & 1.16 & 8.72 & 26.16 & 17.44 & 20.35 & 0.00 & 98.84 \\
\hline Slobozhanskyi & 0.00 & 9.64 & 20.48 & 0.00 & 25.30 & 0.00 & 97.59 \\
\hline Pyriatynskyi & 1.02 & 2.03 & 22.84 & 10.66 & 12.69 & 0.00 & 98.98 \\
\hline Holosiivskyi & 1.28 & 2.55 & 26.38 & 14.47 & 25.53 & 0.00 & 97.02 \\
\hline Mykhailivska Tsilyna & 0.00 & 3.13 & 23.44 & 0.00 & 39.06 & 0.00 & 95.31 \\
\hline Ichnianskyi & 2.06 & 15.46 & 18.56 & 16.49 & 32.99 & 0.00 & 96.91 \\
\hline Mezynskyi & 1.36 & 12.93 & 50.34 & 27.21 & 47.62 & 18.37 & 97.96 \\
\hline Mean & $\mathbf{1 . 1 4}$ & $\mathbf{7 . 3 3}$ & $\mathbf{2 4 . 5 6}$ & $\mathbf{1 4 . 0 0}$ & $\mathbf{2 5 . 9 5}$ & $\mathbf{1 1 . 8 5}$ & $\mathbf{9 7 . 2 0}$ \\
\hline
\end{tabular}


obtusifolius L., Setaria viridis, Senecio vulgaris L., Vicia villosa Roth, Xanthoxalis stricta. Three different habitat types include 57 adventive plant species, amongst them Conium maculatum L., Echinocystis lobata (Michx.) Torr. \& A. Gray, Eragrostis minor, Parthenocissus quinquefolia Planch., Sinapis arvensis L. At the same time, there were no adventive species simultaneously present in all seven types of habitats.

With the increase in anthropophytization index value within each habitat, its saturation with alien species also increases (Table 1). To assess the state of habitats in model floras, we have also calculated anthropophytization index $I_{\text {an }}$ for each of them.

Mean value of $\mathrm{I}_{\text {an }}$ for the habitats of type $C$ is the lowest (1.1\%). This is probably the result of low number of adventive species - only 4 , because the aquatic vegetation belongs to intrazonal vegetation type. Much greater are the index values in habitats belonging to types $F$ and $H$ ( 14.0 and $11.9 \%$, respectively). Biotopes of type $D$ are species deficient and poorly structured; however, because of the direct connection with the most efficient aquatic diaspore transport pathways, invasive species share ranges from 1.4 to $26.9 \%$. Mean value of anthropophytization index $\mathrm{I}_{\text {an }}$ in types $E$ and $G$ habitats is approximately $25 \%$. They are characterised by the complex structure and favourable edaphic conditions for the development and functioning of mesophytic species. In type I habitats, we have recorded the highest $\mathrm{I}_{\text {an }}$ value - about $100 \%$.

\section{Discussion}

According to the distribution of invasive species in secondary ranges in the habitats of model floras, we have calculated the index of biotopic invasibility $\left(\mathrm{I}_{\text {bin }}\right)$. The increase in biotopic invasibility value of the studied object implicates an increase in the capacity of flora for invasive species (Table 2). The proposed index $\mathrm{I}_{\text {bin }}$ reflects the probable level of territory colonisation by identifying potential ecological niches for anthropophytes (which is not considered when using coenotically undifferentiated species lists of all natural and man-made habitats).

T a b l e 2. Characteristics of model floras of Forest Steppe in Ukraine in species composition.

\begin{tabular}{|c|c|c|c|}
\hline \multirow[t]{2}{*}{ Model nature reserve lands } & \multicolumn{2}{|c|}{ Number of species } & \multirow{2}{*}{$\begin{array}{c}\text { Index of biotopical invasibility } \\
I_{b i n}, \%\end{array}$} \\
\hline & Common & Alien species & \\
\hline Pyriatynskyi & 1,077 & 197 & 2.3 \\
\hline Kanivskyi & 1,138 & 172 & 2.5 \\
\hline Holosiivskyi & 1,000 & 228 & 2.7 \\
\hline Dvorichanskyi & 721 & 69 & 3.0 \\
\hline Homilshanski Lisy & 811 & 149 & 3.2 \\
\hline Sviati Hory & 834 & 142 & 3.3 \\
\hline Karmeliukove Podillia & 620 & 121 & 4.0 \\
\hline Feofaniia & 604 & 147 & 4.2 \\
\hline Ichnianskyi & 672 & 97 & 4.5 \\
\hline Slobozhanskyi & 654 & 83 & 4.7 \\
\hline Mezynskyi & 670 & 147 & 5.4 \\
\hline MykhailivskaTtsilyna & 531 & 64 & 6.1 \\
\hline Khotynskyi & 418 & 119 & 7.7 \\
\hline
\end{tabular}


Calculated index showed that the studied floras with the lowest value of $\mathrm{I}_{\text {bin }}$ index (24.5\%) cover large areas (NP Pyriatynskyi, NP Sviati Hory) or represent large integral massifs (NP Dvorichanskyi). They can be characterised by low anthropization with natural flora having the lowest level of transformation. Floras with medium transformation level are characterised by the index value ranging from $4.6 \%$ to $7 \%$, where anthropophytization processes are not yet irreversible (NP Khotynskyi, NR Mykhailivska Tsilyna). In the floras with biotopic invasibility index exceeding 7\%, in some habitat types, alien species (often transformer species) are dominant and radically affect the structural and functional characteristics of the habitat. Mean value of the biotopic invasibility coefficient for the investigated objects is 4.1, whilst the highest value for NP Khotynskyi is 7.7.

Habitats of model floras formed by human activity (type I), included almost $100 \%$ of all recorded alien species. Amongst the natural habitats, the greatest number of alien species was observed in grassland habitats (type E, 35.7\%) and in forests and shrubs (type G, $34.6 \%$ ). They incur direct human impact (mowing, grazing, recreational load, autoregeneration of agricultural lands) and are characterised by the most complex structure and edaphic conditions that are most suitable for the development and functioning of mesophytic species. Other habitat types were colonised by much smaller number of adventive species.

Wide amplitude of anthropophytization index values in type D habitats (1.4-26.9\%) may indicate high colonisation potential of wet grassy habitats because of the low competition and availability of free ecological niches under the appropriate environmental conditions. The level of anthropophytization in type $C$ habitats is the lowest ( $1 \%$ on an average), whilst types $F$ and $H$ habitats have much higher values (14 and 12\%, respectively).

\section{Conclusion}

Proposed index showed the distribution pattern of invasive species by taking into account their share in each of the habitat types, which represents the fullest extent invasibility for model floras and is a differentiated index of alien species share in the flora. Thus, the most monotypic objects (formed by a smaller number of different habitat types), such as NR Mykhailivska Tsilyna, NP Slobozhanskyi and NP Dvorichanskyi, are characterised by the lowest biotopic invasibility value, and that assessment number of IAS present within protected areas using the proposed index has allowed us to establish this pattern. Investigation of the distribution alien species on the protected areas also indicated out that certain types of large areas of natural vegetation reserves can act as a barrier to species. also states that in areas where the protection regime established long ago, the number of species less (Pysek et al., 2003). The study of distribution alien species 93 protected areas (national parks and biosphere reserves) of eight Central European countries (Braun et al., 2016) such trend is denoted (the correlation between the area of the reserve and the number of alien species).

For Central Europe protected areas the most widely occurring species were Fallopia japonica, Heracleum mantegazzianum, Impatiens grandulifera, I. parviflora (Braun et al., 2016), but for Forest-steppe protected areas were Fallopia convolvulus, Vicia angustifolia, Ambrosia artemisiifolia, Phalacroloma annuum, Chenopodium album L., Conyza canaden- 
sis, and most of these species are not invasive. Thus comparison with Central Europe showed a lower level of the alien species pollution of Forest-steppe protected areas in Ukraine.

Amongst the natural habitats most colonised by alien species, making up one-third of habitats' species composition, were grassland, forest and shrubland habitats in the foreststeppe zone of Ukraine. The smallest number, only four adventive species, were recorded in continental waters. The distribution of alien plant species in the habitats of Ukrainian foreststeppe zone is irregular because of the biological and coenotic features of anthropophytes, as well as because of the disturbance in habitat structure and the proximity of diaspore transfer pathways. Despite this, are needed integrated efforts involving science, management and policy, to pave the way for monitoring trends, revising legislation and policies, and improving management of impacts of invasive plants in protected areas.

\section{Acknowledgements}

This worked was funded by the Grant of joint scientific projects competition NAS of Ukraine and RFFR (01-0415). We thank Dr. Tetiana Fitsaylo and Dr. Iryna Korotchenko for kindly furnished phytosociological relevés and Dr. Andriy Mosyakin for helping with the editing in English. We are grateful for the helpful advice of anonymous reviewers.

\section{References}

Abramova, L.M. \& Mirkin B.M. (2000). Evolution of the vegetation on the turn of the millennia. In Teoreticheskie problem ekologii i evolyutsii. Tret' I Lyubishchevskie chteniya (pp. 15-23). Tolyatti: IEVB RAN.

Braun, M., Schindler, S. \& Essl F. (2016). Distribution and management of invasive alien plant species in protected areas in Central Europe. J. Nat. Conserv., 33, 48-57. DOI: 10.1016/j.jnc.2016.07.002.

Braun-Blanquet, J. (1921). Prinzipien einer systematik der pflanzengesellschaften auf floristicher grundlage. Jahrbuch St Gallischen Naturwissenschaftlichen Gesellschaft, 57(2), 305-351.

Burda, R.I., Pashkevych, N.A., Boiko, G.V. \& Fitsailo T.V. (2015). Alien species of protected floras Forest Steppe of Ukraine. Kyiv: Naukova Dumka.

Didukh, Ya.P., Fitsajlo, T.V., Korotchenko, I.A., Iakushenko, D.M. \& Pashkevych N.A. (2011). Biotopes of forest and forest-steppe zones of Ukraine. Kyiv: LLC Macros.

Didukh, Ya.P., Kagalo, A. \& Prots B. (Eds.) (2012). Biotopes (Habitats) of Ukraine: scientific basis of research and inventory results. Workshop proceedings, Kyiv, 21-22nd of March 2012. Kyiv-Lviv.

Foxcroft, L.C., Pyšek, P., Richardson, D.M., Genovesi, P. \& MacFadyen S. (2017). Plant invasion science in protected areas: progress and priorities. Biol. Invasions, 19. DOI: 10.1007/s10530-016-1367-z.

Kagalo, A. \& Prots B. (Eds.) (2012). Habitat concept of biodiversity protection: basis documents of the European Union. Lviv: ZUKC.

Pyšek, P., Jarošík, V. \& Kučera T. (2003). Inclusion of native and alien species in temperate nature reserves: an historical study from Central Europe. Conserv. Biol., 17, 1414-1424. DOI: 10.1046/j.1523-1739. 2003.02248.x. 